\section{Journal of Anatolian Environmental and Animal Sciences (Anadolu Çevre ve Hayvancılık Bilimleri Dergisi) \\ Doi: https://doi.org/10.35229/jaes.641993}

\title{
Brand Management Strategies For Furniture Enterprises: Case Study Of Ordu And Giresun [*]
}

\author{
Emel ÖZTÜRK $^{1^{*}}$ Devrim KARADEMIIR ${ }^{2} \quad$ Emine Seda ERDINLER $^{1}$ \\ ${ }^{1}$ Istanbul University - Cerrahpaşa, Department of Forest Industry Engineering, Istanbul, Turkey. \\ ${ }^{2}$ Ordu University, Social Science Vocational School, Ordu, Turkey. \\ *(D): https://orcid.org/0000-0002-2452-4912, (D): https://orcid.org/0000-0003-1291-7257, (D: https://orcid.org/0000-0002-7814-4333
}

How to cite: Öztürk, E., Karademir, D. \& Erdinler, E.S. (2019). Brand Management Strategies For Furniture Enterprises: Case Study Of Ordu And Giresun. Anatolian Env. and Anim. Sciences, 4(4), 638-642.

Atıf yapmak için: Öztürk, E., Karademir, D. \& Erdinler, E.S. (2019). Mobilya İşletmelerinin Marka Yönetim Stratejileri: Ordu-Giresun Örneği. Anadolu Çev. ve Hay. Dergisi, 4(4), 638-642.

Abstract: In today's dynamic business world, enterprises which are innovative, open-minded, knowledge-creating can keep their assets as powerful players on the market. In this challenging competitive environment, enterprises need a realistic and sustainable vision. Sustainability, recognisability and easy accessibility are important for enterprises. One of the necessities for achievement is an effectively managed brand. Creating effective brand value in the domestic and foreign markets requires strategic moves. Branding is one of the most critical concepts for businesses to reflect themselves and reach their customers.

In this study, it is aimed to determine brand management strategies of furniture enterprises in Turkey. Accordingly, current branding works, brand assets, brand related future plans, how enterprises see their brands in comparison with other brands in the sector, and their views on how their brands are transforming have been determined. In this context, data were collected with survey method from 45 furniture enterprises in Ordu and Giresun provinces in Black Sea Region, Turkey.

As the result of the analysis, $78 \%$ of the enterprises have the moderate technology. The results show that Ordu and Giresun furniture firms are in good communication with their customers, they perceive their expectations / demands, and are easily accessible. $89 \%$ agree that it is important to pay attention to the feelings and needs of the target group and to recognize them well. $73.3 \%$ of the companies make content on social media in the name of branding. It is clear that most popular social media tools are Facebook and Instagram

Keywords: Brand management, Furniture enterprises, SMEs, Turkish furniture industry.

\section{Mobilya İşletmelerinin Marka Yönetim Stratejileri: Ordu-Giresun Örneği}

Öz: Günümüzün dinamik iş dünyasında yenilikçi, değişime açık, bilgi ve değer yaratan işletmeler, bulundukları pazarda güçlü birer oyuncu olarak varlıklarını sürdürebilirler. Bu zorlu rekabet ortamında, işletmelerin gerçekçi ve sürdürülebilir bir vizyon sahibi olmaları gereklidir. Sürdürülebilirlik, tanınırlık ve kolay ulaşılabilirlik kavramları işletmeler için önemli odak noktalarındandır. Bunu sağlamanın gerekliliklerinden biri, pazarda etkin yönetilen bir markaya sahip olmaktır. Yurtiçi ve yurtdışı pazarlarda etkin marka değeri oluşturmak, stratejik çalışmaların varlığını gerektirir. marka yönetimi, işletmelerin kendilerini anlatmaları ve müşterilerine ulaşabilmeleri için en kritik kavramların başında gelmektedir.

$\mathrm{Bu}$ çalışma ile Türkiye mobilya işletmelerinin marka yönetim stratejilerinin belirlenmesi amaçlanmıştır. Buna göre mevcut marka çalışmaları, marka varlıkları, markaları ile ilgili gelecek planları, kendi markalarını sektörde diğer markalar ile karşılaştırıldığında nerede gördükleri, markalarının nasıl bir dönüşüm içinde olduğuna dair görüşlerinin belirlenmesine çalışılmıştır. Bu kapsamda Türkiye'nin Karadeniz Bölgesi'nde yer alan Ordu ve Giresun illerinden seçilen mobilya işletmelerinden, ulaşılan toplam 45 işletmeden anket yöntemi ile veri elde edilmiştir.

Yapılan analiz sonucunda, \%78'inin orta düzey teknolojiye sahip olan Ordu ve Giresun mobilya işletmelerinin müşterileri ile iyi iletişimde oldukları, beklentilerini / taleplerini doğru algılayabildikleri ve markalarının kolay erişebilir olduğu görülmektedir. Marka imajı, müşterilerin karar alma süreçlerini olumlu etkilemekte ve şirketler (\%89) hedef gruplarına önem vermektedir. İşletmelerin \%56' s1 marka “dönüşüm/ yeniden yapılanma” sürecinde bulunmaktadır. Şirketlerin \% 73,3' ü sosyal medyada markalaşma / marka geliştirme/ sürdürülebilirlik tanıma/ geliştirme adına internet kanallarında içerik ürettiklerini belirtmişlerdir. En popüler sosyal medya araçları Facebook ve Instagram olmuştur. 


\section{INTRODUCTION}

Nowadays, the use of the brand as a marketing variable is an important competitive tool for businesses. For this reason, it is important for businesses to decide which brand strategy to apply. Whatever brand strategy is used, the foundation for the implementation of brand strategies (brand architecture) for businesses is a strategic tool. The selected brand strategy will be a significant influence on the effectiveness of the marketing efforts of the enterprises (Sönmez, 2010).

The traditional approach is to communicate with the customer through only a few channels such as radio, television, printed media, etc., as it is not too difficult to convince the customer, and because the competition is not too much; most of the company's products could easily be sold, and the customer itself is not in big expectation. The customer basically concerns about the functional benefits of the product buys the product or service accordingly. Consumers can compare all brands in a very short time. It basically focuses on its own benefit. Even in the face of a small mistake, the brand can leave. In such a challenging environment, the best means of competition is to 'become a brand'. The main goal of every company should be building the brand in minds. The most competitive advantage in the current business world is to become a brand and to have branded products (Ünalan, 2015).

The main aim of the branding is to gain competitive advantage through distinctiveness, awareness and the emotional plus benefit-based relationship established by the consumer and the customer. The branding effort may also aim to provide a distinction based on a product, idea or image. In order to create and manage a successful brand, it is necessary to recognize the target consumer or potential customers according to their motivation, enjoyment, preferences, needs, and expectations. In order to ensure successful branding, the processes such as identity, positioning and awareness of the brand are carried out without supporting the objectives of the campaign and supporting each other (Alikişioğlu, 2012).

Whatever the size of their enterprise is, there are certain features that make sense for current and potential employees. These features are the reasons why they prefer the enterprise. These features cause a sense of branding in the minds of people about the business. The studies have shown that employees who have a strong employer brand increase their level of commitment, their motivation and performances, the number and quality of applications and accumulate more qualified employees in their organizations, where also decrease recruitment costs, make long term impact, increase managerial satisfaction, culture, and their competitiveness (Baş, 2011).

The strategy is a kind of plan. It is more dynamic than routine plans and requires $t$ the competitors' possible actions that can affect the outcome of the business (Baş, 2011). Markets should have a vision with awareness of change, and can make the brand live in the long run with integrated strategies by taking the appropriate steps (Ünalan, 2015).

The brand strategy is expressed as a long-term plan to achieve the brand's goals. However, if there is a confusion that the brand is a product, name, website or logos in the company, it is necessary to understand that the concept of the brand is not only a complementary element, but also includes the values, feelings, habits and place of the consumer. Every day, a new brand enters to the market and consumers come across a physical or digital brand bombardment. Brands willing to exist without being victims of the consumer's tiredness need to reflect their company's goals on their brands and determine their commitment to the consumer's contribution to life with clear lines. As new channels appear every day, the communication, the word, the message and the visual in each channel need to show a consistent line, attitude and expression. Consistent activities that increase the brand's recognition acceleration also serve as a reinforcer in terms of customer loyalty. To carry out the communication demanded by the new generation consumers, to smooth the transition between the electronic devices, to adopt the language of the mark with the platform's own language and to make the messages invisible but powerful, are the notes leading to the success of the consistency move (Moralıoglu, 2016).

Global companies, that is, brands operating in international markets, need to apply strategies that are in line with the local values of the different countries in which they operate. When the local customer expectations, culture structure, habits, traditions, lifestyle etc, are understood and are not adapted accordingly, the products can not be kept in new and different markets, can't be successful and in a short time, they may have to leave the market or change products. While products are adapted accordingly to socio-cultural differences, the factors such as climatic conditions of the local market, development levels of countries, religious structure, income level, packaging and labeling, taste should be considered. In addition, it is also possible for companies to maintain their brand identities using global messages, while making appropriate adjustments to their market. However, if the given current message is contradictory to the cultural or product that is adapted to the country, it may be necessary to create a completely new message (Moralıoglu, 2015). It is stated that Turkish firms do not follow a certain analysis method when they enter new export markets and therefore major parts of the big picture are not noticed (Gider, 2016).

One of the most important branches of the Turkish forest products industry is the furniture industry. Turkish furniture industry has a heterogeneous structure which is consisted numerous enterprises with micro and macro structure. Because of these heterogeneous structures and the multiplicity of structural and economic problems they have, enterprises need the change and improvement. Customers are at the forefront of effective determining factor when most of 
the business are taking a decision. This study is aimed to determine brand management strategies of furniture enterprises. Accordingly, current brand studies, brand assets, future plans related to brands, how their brands are seen in comparison with other brands in the sector, and their views on how their brands are transforming have been determined.

\section{MATERIAL and METHODS}

The main purpose of the research is to determine brand management strategies of furniture companies. The brand assets of the furniture enterprises, the importance of perceiving the brand value and the importance given to the brand have been questioned.

The sample of the survey is limited to the provinces of Ordu and Giresun in the Black Sea region of Turkey. It has been targeted to reach all the furniture enterprises operating in Ordu and Giresun.

The survey form was used as data and information gathering tool in the research. The prepared questionnaire was applied on a sample and the clarity and clarity of the questions on the questionnaire were tested. With the information gathered, necessary regulations were made in the questionnaire form and the questionnaire form was put into practice. Surveys were conducted with authorized interviewers at face-to-face meetings. Survey work was created via Google Drive and responded online by sending them to their email address. 45 enterprises responded the questionnaire forms. The survey was conducted in July and August 2018.

The data considered in the study consist of demographic information for determining the characteristics of the enterprises and statements aimed at evaluating the brand management strategies of the enterprises 5 Likert scale (Strongly Agree, Agree, Undecided, Disagree, Strongly Disagree), yes / no questions and multiple choice questions were used to the evaluations of the enterprises being questioned with 23 items.

\section{RESULTS}

Demographic Information: The furniture enterprises participating in the survey, $66,7 \%$ were in Ordu (30 enterprises) and 33,3\% were in Giresun (15 enterprises). $62,2 \%$ of Participating Enterprises are Private Company, $33,3 \%$ are Limited Companies and 4,4\% are Joint Stock Companies. When the distribution of enterprises according to the years of establishment is examined, it is observed that the enterprises established between 2001 and 2010 (33,3\%) and the enterprises established between 1981 and $1990(31,1 \%)$ are concentrated. Then, $15,6 \%$ are from 1991-2000, 15,6\% are from 2011 and after, and 4,4\% are from 1980 and before.

$55,6 \%$ of the respondents are business owners, $22,2 \%$ are professional managers, $11,1 \%$ are engineers / architects / technicians, $11,1 \%$ are employees. $84,4 \%$ were male and $15,6 \%$ were female. $33,3 \%$ of the respondents were aged $33-39,28,9 \%$ were aged 40-46, 13,3\% were aged 47-53, $11,1 \%$ were aged $26-32,6,7 \%$ are $19-25$, and $6,7 \%$ are in the 53 and over age group. According to educational status, $42,2 \%$ of respondents were university graduates, $26,7 \%$ were vocational high school graduates, $15,6 \%$ were high school graduates, $8,9 \%$ were primary education graduates, $4,4 \%$ were secondary education and $2,2 \%$ is postgraduate people.

$31,1 \%$ of the enterprises were in the organized industrial zone, $31,1 \%$ were in the urban neighbourhood, $31,1 \%$ were the small industrial sites and $6,7 \%$ were in the free zones. Number of employees was between 1-9 in $64,4 \%$, between $10-49$ in $33,3 \%$, and between $50-249$ in $2,2 \%$. There were no businesses with 250 employees. There were 9 engineers, 12 architects, 28 technicians and 11 industrial designers. It was stated by managers that $77,8 \%$ of the enterprises had medium level technology, 20\% had high level technology and 2,2\% had low level technology. The average capacity rate of the enterprises in the last one year was $63 \%$ on average.

Assessment of Brands and Process for Orientation to National/International Target Markets Conceptual Awareness: The ratios of strongly agree and agree responses from 23 questions prepared at the 5-Likert scale (Strongly Agree, Agree, Undecided, Disagree, Strongly Disagree) are shown in Table 1.

In the brand communication, the percentage of the enterprises using social media is $86,7 \%$. The most used social media channels in brand communication are Facebook and Twitter. This is followed by WhatsApp, Twitter, Google+ and Linkedin respectively. YouTube, Pinterest, Skype, Snapchat, social media channels have never been used. Firms that did not use any social media channels accounted for $4,4 \%$. The distribution of social media usage according to the establishment years of the enterprises is shown in Table 2 and 3 .

The factors that play an important role in the continuity of the brand from the enterprises were required to be marked. According to this, the answers given by the enterprises are shown in Table 4 as percentage and frequency distribution. Enterprises are most likely to attach importance to an innovative, sustainable vision and trust-based criterion.

$73,3 \%$ of the enterprises gave a positive answer where $26,7 \%$ answered no, for the question "Do you produce content in the name of branding / brand development / sustainability recognition / development in social media?".

The first 3 tool markings which are most important for the brand promotion are requested to mark from the enterprises. According to the this, in decreasing order, 73,3\% brochures / catalogs, 60\% social media groups, 53,3\% magazines / newspapers / other printed publications, $20 \%$ fairs / invitations and similar events, 20\% internet advertising, $17,8 \%$ TV commercials, $8,9 \%$ cinema take place. 
Table 1. Brand evaluations of enterprises.

\begin{tabular}{lc}
\hline & Percentage (\%) \\
\hline We are recognized by our customers (our target kit). & $91 \%$ \\
It is important to give importance to the feelings and needs of the target group and to recognize them well. & $89 \%$ \\
Customers can easily contact us when they have problems with our brand. & $87 \%$ \\
Our mark affects our target customers' purchasing decision positively. & $84 \%$ \\
We can perceive our customers' expectations / demands correctly & $84 \%$ \\
We can quickly catch up with our clients' new demands or even more difficult expectations. & $84 \%$ \\
It is important to whom our mark will address (target not set). & $82 \%$ \\
Meeting our customer requirements is our high performance & $82 \%$ \\
Positive relations with major customers / units in the sector & $82 \%$ \\
Producing the right content for branding / branding is very important. & $80 \%$ \\
We are striving to develop products and services that will strengthen our reputation and market perception & $80 \%$ \\
We are a brand that can provide effective solutions to our customers' problems in short time. & $80 \%$ \\
We follow the judgments and values created by our products and services in the market. & $76 \%$ \\
We are recognized in the market we are in. & $76 \%$ \\
We are a powerful player in the market we find. & $62 \%$ \\
We have efforts to increase brand value. & $60 \%$ \\
Our mark is in a "transformation / restructuring" process. & $56 \%$ \\
We have an actively managed brand. & $51 \%$ \\
We are actively using advertising channels on the domestic market. & $40 \%$ \\
We have a brand value at Turkey market. & $24 \%$ \\
We receive corporate communication consulting. & $20 \%$ \\
We have a brand value in the overseas market. & $13 \%$ \\
We are actively using advertising channels in international markets. & $9 \%$ \\
\hline
\end{tabular}

Table 2: Distribution of social media usage by establishment's years.

\begin{tabular}{lccccccc}
\hline & Facebook & Instagram & WhatsApp & Twitter & Google+ & LinkedIn & Not Using \\
\hline 1980 and before & 2 & 2 & 1 & - & - & - & - \\
$1981-1990$ & 10 & 12 & 4 & 1 & 1 & 3 & 1 \\
$1991-2000$ & 4 & 4 & 3 & - & 1 & - & - \\
$2001-2010$ & 13 & 11 & 8 & 3 & 1 & 1 & - \\
2011 and after & 6 & 5 & 3 & 1 & - & - & 1 \\
\hline Total & $\mathbf{3 5}$ & $\mathbf{3 4}$ & $\mathbf{1 9}$ & $\mathbf{5}$ & $\mathbf{3}$ & $\mathbf{4}$ & $\mathbf{2}$ \\
\hline
\end{tabular}

Table 3: Usage rates of social media channels in communication.

\begin{tabular}{ccccccc}
\hline Facebook & Instagram & WhatsApp & Twitter & Google+ & LinkedIn & Not Using \\
\hline $78 \%$ & $76 \%$ & $42 \%$ & $11 \%$ & $7 \%$ & $9 \%$ & $4 \%$ \\
\hline
\end{tabular}

Table 4: Distribution of factors that play a role in the continuity of the brand.

\begin{tabular}{lcc}
\hline & Number of answers & Percentage $\%$ \\
\hline Innovative, sustainable vision based on strong foundations & 32 & $71,1 \%$ \\
To be dependable & 28 & $62,2 \%$ \\
To be able to update the business according to the trends of the day & 26 & $57,8 \%$ \\
Gaining reputation & 25 & $55,6 \%$ \\
To be open to innovation & 19 & $42,2 \%$ \\
To create a better impression & 17 & $37,8 \%$ \\
\hline
\end{tabular}

\section{DISCUSSION and CONCLUSION}

In today's dynamic business world, enterprises which are innovative, open-minded, knowledge-creating can be keep their assets as powerful players on the market they are in. In this challenging competitive environment, enterprises need to have a realistic and sustainable vision. Sustainability is an important focus for enterprises. Being recognizable and easy accessibility are the goals of each enterprise. One of the necessities to achieve this is to have a brand that is effectively managed on the market. Creating effective brand value in the domestic and foreign markets requires the existence of strategic studies. In the competitive environment where there is a rapid change and transformation, brand concept is one of the most critical concepts for enterprises to express themselves and reach their customers.
In this context, data were collected with survey method from 45 furniture enterprises reached from Ordu and Giresun provinces which are located in Black Sea Region of Turkey. Given the demographic structure of the respondents, two-thirds of the enterprises are in Ordu and one-third of those are in Giresun. Private companies (62,2\%) and enterprises established between 1981 and 2010 are concentrated. The vast majority of respondents were business owners and university graduates. It has been determined that $77,8 \%$ of the enterprises have the moderate technology, $20 \%$ have high technology and average capacity utilization rate is $63 \%$ in the last one year.

Most of the furniture companies of Ordu and Giresun $(91 \%)$ stated that they are recognized by the customers, namely the target groups. A similar majority $(89 \%)$ stated that they agree that "it is important to pay attention to the feelings and needs of the target group and to 
recognize them well." The results show that Ordu and Giresun furniture firms are in good communication with their customers, they can correctly perceive their expectations / demands, and they are easily accessible to brands.

It is seen that brand images have a positive effect on the decision-making process of the customers and that they attach importance to the target groups of the companies. Enterprises stated that their customers are able to keep pace with their new demands or more difficult expectations and those they have a high level of success in meeting customer needs and are able to provide effective solutions to their customers' problems in a short period of time. It is seen that the relations with important customers/units in the sector are also positive.

Enterprises are aware that producing the right content for branding / branding is very important. They are also endeavouring to develop products and services that will strengthen their reputation and market perceptions. Enterprises are known in the market and they are following the judgments and values of the products and services in the market. $62 \%$ of the enterprises see themselves as a strong player on the market they are in. There are studies to increase brand value, and again at similar rates $(56 \%)$, their brands are in a "transformation / restructuring" process. Considering all these positive views, only $51 \%$ of companies have indicated that the brands were effectively managed. The effective use of advertising channels in the domestic market (40\%) was found to be quite low in spite of the high recognition of their company in the market. The proportion of businesses indicating that they have a brand name in Turkey's market value was $24 \%$. Participants in the survey indicated that only one of the furniture companies had corporate communication consultancy. Only $13 \%$ of firms have a brand value in the international market and $9 \%$ have used advertising channels effectively in international markets.

$73,3 \%$ of the companies stated that they were producing content on the internet in the name of branding / brand development / sustainability recognition / development on social media.

Brochures / catalogues $(73,3 \%)$, social media groups $(60 \%)$, magazines / newspapers / other printed publications $(53,3 \%)$ are the most important means of brand promotion of businesses. Fair / invitation etc. events, internet advertising, TV commercials, cinema have become the least preferred brand promotion channels.

According to the general structures, firms that are seen as micro, small and medium scale are known as brands on the market they are in, but they are not yet located in the domestic market all over the country. The fact that they are working on brand management shows that businesses are conscious of this issue and their awareness levels are in good condition. There are fewer companies that target overseas markets and work in this field. This may be attributed to the fact that the majority of businesses are micro and small-scale local businesses.
It seems that YouTube channel has never been used by enterprises. However, the prospective customer group in the near future is now heavily following YouTube. Enterprises should also use the social media tools to reach young people in their 18-24 of age group who are the new generation, that is called the future customers.

\section{ACKNOWLEDGEMENTS}

Supporting the implementation of the survey study, We would like to thank to Lec. Gökay Civelek, Yağmur Yücel and the furniture companies in Ordu and Giresun who responded by taking the time to answer the questionnaire.

\section{REFERENCES}

Alikişioğlu, M. (2012). Reklamın iyisi. Optimist Yayınları, İstanbul, 299p.

Baş, T. (2011). İşveren markası. Optimist Yayınları, İstanbul, 165p.

Gider, B. (2016). Pragmatik pazara giriş stratejisi: go-tomarket. http://hbrturkiye.com/blog/pragmatikpazara-giris-stratejisi-go-to-market-strategy. Last access: 07 February 2018.

Moralığlu, D. (2015). Marka stratejisinde yerel kültür belirleyici. https://hbrturkiye.com/blog/markastratejisinde-yerel-kultur-belirleyici. Last access: 21 May 2018.

Moralığlu, D. (2016). Marka stratejinizin ayaklarını tantyın. https://hbrturkiye.com/blog/markastratejinizin-ayaklarini-taniyin. Last access: 18 April 2018.

Sönmez, E. (2010). Markalama stratejilerine genel bir bakış. Adlyaman Üniversitesi Sosyal Bilimler Enstitüsü, 3(5), 227-238.

Ünalan, M. (2015). Rekabet avantajı olarak marka ve markanın sürdürülebilirliği. https://hbrturkiye.com/blog/rekabet-avantaji-olarakmarka-ve-markanin-surdurulebilirligi. Last access: 21 May 2018.

\footnotetext{
*Corresponding author's:

Emel ÖZTÜRK

Istanbul University - Cerrahpaşa, Department of Forest Industry Engineering, Istanbul, Turkey.

E-mail : emelozt@istanbul.edu.tr

ORCID : https://orcid.org/0000-0002-2452-4912
} 